\title{
Study of Genetic variability for different traits in Soybean
}

\author{
Sidramappa*, C. R. Konda and M. Shobharani \\ Agricultural Research Station, Bidar, UAS, Raichur, India \\ *Corresponding author
}

\begin{tabular}{l} 
Ke y w o r d s \\
Soybean, \\
Genetic variability, \\
heritability, \\
GCV, PCV \\
Article Info \\
$\begin{array}{l}\text { Accepted: } \\
28 \text { November } 2019 \\
\text { Available Online: } \\
10 \text { December } 2019\end{array}$ \\
\hline
\end{tabular}

A B S T R A C T
An experiment was conducted to study genetic variability present in the thirty six genotypes and observations were recorded on various yield and yield contributing characters viz., days to $50 \%$ flowering, days to maturity, plant height, number of branches per plant, number of pods per plant, 100 seed weight and grain yield per plant. Analysis of variance revealed highly significant differences among the genotypes for the all the characters. High PCV and GCV were observed for branches per plant, pods per plant and yield per plant indicate the presence of wider adaptability for these traits in the genotypes studied, suggested the less influence of environment in the expression of characters. High heritability coupled with high genetic advance as percent of mean was observed for days to $50 \%$ flowering, plant height, branches per plant, pods per plant, 100 seed weight and seed yield per plant indicating operation of additive gene action and the ample scope for improvement in these traits through simple selection.

\section{Introduction}

Soybean [Glycine $\max (\mathrm{L}$.$) Merrill] is a major$ oil seed crop in the world and is called as a golden bean or miracle bean because of its nutritional qualities having $20 \%$ oil and 40 percent protein, which has biological value as meat and fish protein and rich in amino acids like lysine and tryptophan. Genetic variability is the basic requirement for crop improvement as this provides wider scope for selection. Thus, effectiveness of selection is dependent upon the nature, extent and magnitude of genetic variability present in material and extent to which it is heritable. Hence, in present investigation an attempt was made to assess the variability of pod yield and yield contributing traits, along with genotypic coefficient of variation (GCV), phenotypic coefficient of variation (PCV), heritability, genetic advance (GA) and genetic advance as percent of mean $[1,2]$.

\section{Materials and Methods}

The experimental materials consist of 36 genotypes of soybean. These genotypes of soybean were evaluated in randomized block design with three replications at Agricultural Research Station, Bidar during kharif, 2014. 
Each genotype was sown in three rows of 3.0 m length with a spacing of $45 \mathrm{~cm} \times 15 \mathrm{~cm}$. Observations on seven characters were recorded on randomly selected five plants from each genotype and average value was used for statistical analysis. The data is subjected to different statistical analysis viz., analysis of variance, magnitude of genetic variability were performed following standard procedures.

\section{Results and Discussion}

Analysis of variance revealed highly significant and exploitable variability among all the genotypes for twelve characters (Table 1). Greater variability in the initial breeding materials ensures better chances of producing desired recombinants for improvement of the crop. This suggests the presence of variation among the genotypes for all these traits. The phenotypic (PCV) and genotypic (GCV) coefficient of variation for the seven characters during kharif 2014-15 have been presented in Table 2. In general, the magnitude of phenotypic coefficient of variation was higher than the corresponding genotypic coefficient of variation for all the traits [1]. In the present investigation, days to $50 \%$ flowering recorded moderate phenotypic and genotypic coefficient of variation indicating that there is a scope for improvement of this trait. Partitioning of total variance into its components revealed that phenotypic coefficient of variation and genotypic coefficient of variation were low in magnitude for days to maturity. The values for GCV and PCV for plant height $(\mathrm{cm})$ revealed that the magnitudes of GCV \& PCV were moderate for this trait [6,7]. Number of branches per plant recorded high value of GCV and PCV indicates the greater role of genetic factor in influencing the expression of the character. GCV and PCV were high for number of pods per plant, suggesting wide spectrum of genotypic variation for this trait. [9] Reported high magnitudes both GCV and PCV for no.of pods per plant in soybean. The estimates of PCV \& GCV were high for seed yield per plant [4]. In general, the estimates of genotypic and phenotypic coefficient of variation were high for Branches per plant, pods per plant and seed yield per plant. Moderate magnitudes of GCV and PCV were observed for days to $50 \%$ flowering, plant height and 100 seed weight, whereas, low estimates of GCV and PCV were expressed by days to maturity.

Genotypic coefficient of variation measures the amount of variation present in particular character. However, it does not determine the proportion of heritable variation present in the total variation. Therefore, heritability which represents the heritable variation existing in the character was calculated. High value of heritability and low genetic advance expressed as percentage of mean suggested that this character was conditioned by high genotypeenvironmental interaction. In such a situation, selection would not be rewarding.

Table.1 Analysis of Variance for yield and yield attributing characters

\begin{tabular}{|l|c|r|r|r|r|r|r|r|}
\hline $\begin{array}{l}\text { Source of } \\
\text { Variation }\end{array}$ & df & $\begin{array}{c}\text { Days to } \\
\text { 50\% } \\
\text { flowering }\end{array}$ & $\begin{array}{c}\text { Days to } \\
\text { maturity }\end{array}$ & $\begin{array}{c}\text { Plant height } \\
\text { (cm) }\end{array}$ & $\begin{array}{c}\text { Branches } \\
\text { per plant }\end{array}$ & $\begin{array}{c}\text { Pods per } \\
\text { plant }\end{array}$ & $\begin{array}{c}\text { 100 seed } \\
\text { weight (g) }\end{array}$ & $\begin{array}{c}\text { Seed yield } \\
\text { per plant (g) }\end{array}$ \\
\hline Replication & 2 & 1.335 & 1.236 & 7.021 & 0.902 & 10.216 & 0.751 & 2.154 \\
\hline Treatment & 36 & 55.561 & 183.012 & 203.125 & 2.215 & 215.150 & 9.561 & 35.142 \\
\hline Error & 72 & 1.023 & 1.401 & 8.231 & 0.678 & 8.024 & 1.234 & 1.051 \\
\hline
\end{tabular}


Table.2 Parameters of genetic variability for various yield and yield contributing traits of

\begin{tabular}{|c|c|c|c|c|c|c|c|c|}
\hline \multicolumn{9}{|c|}{ soybean } \\
\hline Sl.No. & Traits & Range & Mean & $\begin{array}{l}\text { PCV } \\
(\%)\end{array}$ & $\begin{array}{l}\text { GCV } \\
(\%)\end{array}$ & $\begin{array}{c}\text { Heritabi } \\
\text { lity (bs) } \\
(\%)\end{array}$ & $\begin{array}{c}\text { Genetic } \\
\text { advance }\end{array}$ & $\begin{array}{c}\text { Genetic } \\
\text { advance as } \\
\text { per cent } \\
\text { mean }\end{array}$ \\
\hline 1 & Days to $50 \%$ flowering & $37.00-46.00$ & 41.51 & 11.18 & 10.89 & 91.25 & 8.38 & 20.19 \\
\hline 2 & Days to maturity & $90.00-109.00$ & 98.63 & 8.37 & 8.3 & 94.70 & 17.95 & 18.20 \\
\hline 3 & Plant height $(\mathrm{cm})$ & $32.00-56.00$ & 46.13 & 19.05 & 18.13 & 86.94 & 17.91 & 38.83 \\
\hline 4 & Branches per plant & $2.30-5.00$ & 2.62 & 31.92 & 30.56 & 88.00 & 1.51 & 57.63 \\
\hline 5 & Pods per plant & $18.00-52.00$ & 31.84 & 38.19 & 37.26 & 91.57 & 22.43 & 70.45 \\
\hline 6 & 100 seed weight $(\mathrm{g})$ & $10.80-17.60$ & 12.84 & 13.9 & 12.76 & 80.63 & 3.09 & 24.07 \\
\hline 7 & Seed yield per plant $(\mathrm{g})$ & $4.31-16.22$ & 9.12 & 40.44 & 38.51 & 87.06 & 6.04 & 66.23 \\
\hline
\end{tabular}

The estimates of genetic parameters revealed that Days to $50 \%$ flowering expressed high heritability coupled with high genetic advance as percent of mean of this trait indicates the operation of additive genes and offer the best possibility for improvement of this trait through mass selection, progeny selection, family selection to any other suitable modified selection procedure aiming to exploit the additive gene effects[4]. High heritability along with moderate genetic advance as percent of mean as observed in the present study for Days to maturity indicates the predominance of additive gene action in the expression of this trait. High heritability coupled with high genetic advance as percent of mean was recorded indicates the predominance of additive gene action in the expression of Plant height [11,12]. The magnitude of heritability in broad sense was high coupled with high genetic advance as percent of mean for Number of branches per plant. The results suggest that there is a wide scope for improvement of this trait through simple selection procedure. High heritability and genetic advance expressed as percent of mean was high for Number of pods per plant [8,11]. High heritability coupled with high genetic advance as percent of mean of this trait indicates the operation of additive genes and offer the best possibility for improvement of this trait through mass selection, progeny selection, family selection to any other suitable modified selection procedure aiming to exploit the additive gene effects [9]. High heritability coupled with high genetic advance as percent of mean for 100 seed weight $(\mathrm{g})$ indicates the operation of additive genes and offer the best possibility for improvement of this trait through mass selection, progeny selection, family selection to any other suitable modified selection procedure aiming to exploit the additive gene effects [3].

High heritability coupled with high genetic advance as percent of mean was recorded indicates the predominance of additive gene action in the expression of Seed yield Per Plant (g). The results suggest that there is a wide scope for improvement of this trait through simple selection procedure [12].Thus, from the present investigation, it can be concluded that high genetic advance was not always associated with high heritability for the characters studied.

\section{References}

1. Agrawal, A. P.; Patil, S. A. and Salimath P. M. 2001. Variability, heritability and genetic advance of some quantitative characters over the seasons in soybean. Madras Agric. J., 88 (1-3) : 36-40.

2. Baraskar, V.V., Kachhadia, V.H., VachhanI, J.H., Barad, H.R., Patel M.B. and Darwankar, M.S., 2014.Genetic variability, heritability and genetic advance in soybean (Glycine $\max$ (L.) Merrill). 
Electronic Journal of Plant Breeding, 5(4): 802-806.

3. Burton, G. W. 1952. Quantitative Inheritance in Grasses. Proc. 6th Int. Grassland. Cong ., $1: 227-283$.

4. Sood V K and Sood O P. 2001. Effect of cropping system on some genetic parameters in soybean [Glycine $\max (\mathrm{L}$.) Merrill]. Indian Journal of Genetics and Plant Breeding 61: 132-135.

5. Ramana M V, Pramila Rani B and Satyanarayana A. 2000. Genetic variability, correlation and path analysis in soybean. Journal of Oilseeds Research 17: 32-35.

6. Bangar N D, Mukhekar G D, Lad D B and Mukhekar D G. 2003. Genetic variability, correlation and regression studies in Soybean, Journal of Maharashtra Agricultural Universities 28:320-321.

7. Gohil V N, Pandya H M and Mehta D R. 2006. Genetic variability for seed yield and its component traits in soybean.
Agricultural Science Digest 26 (1):73-74.

8. Thorat A Khorgade P W, Ghorade and Ghodke M. 1999. Variability, heritability andGenetic advance in soybean [Glycine $\max$ (L.) Merrill]. Journal Soils and Crops 9: 198-200.

9. Ramana M V. 2003. Genetic studies on soybean (Glycine max (L.) Merrill) in nontraditional areas and seasons. Ph.D Thesis ANGR Agricultural University, Hyderabad.

10. Hina Kausar. 2006. Genetic investigations in segregating populations of soybean [Glycine max (L.) Merrill]. Karnataka Journal of Agricultural Sciences 19 (1): 200.

11. Sriranjani K, Ramana M V, Srinivasa Roa V and Rama Kumar P V. 2007. Correlation and path analysis in soybean (Glycine max (L.) Merrill). The Andhra Agricultural Journal 54: 6-8.

\section{How to cite this article:}

Sidramappa, C. R. Konda and Shobharani, M. 2019. Agricultural Research Station, Bidar, UAS, Raichur, India. Int.J.Curr.Microbiol.App.Sci. 8(12): 2991-2994. doi: https://doi.org/10.20546/ijcmas.2019.812.347 